\title{
The Concepts of Teachers of Brazzaville on the Evaluation in Physical Education in High School
}

\author{
Mabassa David Sylvain ${ }^{1}$, , Lembe Gorgon ${ }^{1}$, Koulombo Armel ${ }^{1}$, Itoua Okemba Jean ${ }^{2}$ \\ ${ }^{1}$ Laboratory of Didactics of Physical Education, Higher Institute of Physical Education, Marien Ngouabi University, Brazzaville, Congo \\ ${ }^{2}$ Laboratory of Physical and Adapted Activities, Higher Institute of Physical Education, Marien Ngouabi University, Brazzaville, Congo
}

\section{Email address:}

dmabassa@googlemail.com (M. D. Sylvain),drgorgonlembe@gmail.com (L. Gorgon), koulomboarmel@gmail.com (K. Armel), jeanokemba1956@gmail.com (I. O. Jean)

*Corresponding author

\section{To cite this article:}

Mabassa David Sylvain, Lembe Gorgon, Koulombo Armel, Itoua Okemba Jean. The Concepts of Teachers of Brazzaville on the Evaluation in Physical Education in High School. International Journal of Sports Science and Physical Education. Vol. 5, No. 2, 2020 , pp. 10-15. doi: $10.11648 /$ j.ijsspe.20200502.11

Received: July 10, 2020; Accepted: July 30, 2020; Published: August 10, 2020

\begin{abstract}
The purpose of this study is to analyze teachers' views on the evaluation of physical education as a teaching discipline. The specific objective is to identify the way in which his teachers adapt their learning theories to physical sports and artistic activities. Because his teaching practice is often subject to readjustments during the exhibitions of body movements on the ground. The study was conducted in Brazzaville involving 179 physical education teachers working in high schools. Teachers were interviewed using a questionnaire with open and closed questions that focused exclusively on the operational and conceptual implementations of formative and summative assessments. Then, a field of questioning divided into several items was adapted to the Likert scale of attitude at 4 levels. The results obtained show that the teaching practices of physical education teachers are very varied, there is a persistence on the traditional and summative side of the evaluation. Thus, the formative evaluation is regularly diverted from its initial function, it is noted, and creates a confusion of educational purposes.
\end{abstract}

Keywords: Conceptions, Teachers, Physical Education, Assessment

\section{Introduction}

The training of physical education teachers (PE) is regularly reformed, torn between the high demand for professionalization and the provision of theoretical data on physical sports and artistic activities from training centers. If theory and practice appear to be interdependent to ensure coherent training, the links between these two entities are complex. Putting into practice the knowledge taught in training brings out all the complexity of the teaching situation of physical sports and artistic activities, requiring an adaptation to the context which is not very predictable especially for beginner teachers [1]. Despite official recommendations and contributions from research in physical education (PE), teachers have pedagogical freedom and the choice of a didactic approach [2]. Indeed, the official texts reflect the aims of physical education, and the teacher determines the means of achieving it. The methods used are widely personalized and on the one hand reflect the identity of the physical education teacher, making the comprehensive analysis of physical and artistic practices both relevant and complex. The current work of the Chicago School [3] takes into account in the analysis of motor behaviors, the weight of the context and the meaning that students have of learning situations in physical education. This interactionist conception allows us to take a look at the enduring tradition, at the physical and sporting practices that change little, even if the rating code encourages us to do otherwise [4]. In this context, it is necessary to distinguish, in the work of educator, that which falls under the prescription and the actual achievements of the teachers, because as Leplat indicates: "l 'physical activity depends very much on the task (or if one prefers external working conditions), but also on the characteristics of the pupils who perform it' [5].

The fundamental problem of our study is centered here on the evaluative activity of high school physical education teachers. Being compulsory according to the Orientation law on education in the Republic of Congo, where it is mentioned 
that teachers provide individual monitoring and evaluation of students, evaluation in all its forms involves gathering information, confrontation between a referee and a referent, the result of which leads to decision-making. Today, we agree that physical education assessment is a necessary step in a motor learning process in schools. It is one of the specific skills to be developed by physical education teachers who, in training, are already aware of theoretical resources and are also going through practical analysis workshops. Even if evaluation is a subject shared by the teaching disciplines, it is the subject of transversal publications [6], but also more specific, as part of the disciplinary didactics. In addition, physical sports and artistic activities are mostly oriented towards the analysis of practices, towards the difficulties encountered by beginner teachers, even by students. Physical education also has specific evaluation methods such as motor control in time and space, that is to say a spatio-temporal representation of the activity. Hence, physical education teachers directly assess the scope of their teaching.

In the same vein, Braxmeyer et al. have shown that teachers of physical education are largely distinguished from teachers of other disciplines by making greater use of assessments for diagnostic, formative and summative purposes [7]. These implementations are used to create need groups and individualize motor learning. Thus, our study aims to question the evaluative practices of physical education teachers with regard to two main hypotheses: 1- physical sports and artistic practices are far from being standardized, they evolve with the level of expertise. 2- formative and summative evaluations are confused by physical education teachers, because the use of notation seems contradictory and causes a discrepancy between the teacher's formative intentions and the proposed learning situations.

In Congolese schools, the implementation of physical education assessments poses specific problems. For example, the bias of ultimately teaching only what is evaluated to implement precise and objective evaluation procedures. We started from the premise that the physical education teacher from Brazzaville adapts his implementation according to his conceptions and the situation in which he evolves, while relying on current approaches oriented towards a formative approach. The purpose of the study presented here is to understand the differences in implementation that reflect different interpretations of a common culture of evaluation. It also testifies to the difficulties in teaching materials encountered by teachers to put into practice the knowledge they have acquired and to detach themselves from the summative side. Will the difficulties pointed out by theorists or raised during our empirical observations in the field appear in the results of our survey?

\section{Methodology}

\subsection{Study Framework}

Our study took place in public high schools of general education in Congo-Brazzaville, during the 2018-2019 school year. This choice of these educational establishments is justified by the availability of adequate teaching materials for good practice physical sports and artistic activities.

\subsection{Participants}

The study population was made up of 179 physical education teachers working in high school. The teachers interviewed had the grade of certified physical education teacher with professional experience of 5 years and more. Thus, $55 \%(\mathrm{n}=99)$ of the teachers interviewed were men, compared to $54 \%(\mathrm{n}=80)$ nationally. The share of aggregates is higher, all of the civil servants who make their money from the Congolese state budget, ie $100 \%$ of the employees, accepted our survey. Finally, the average age was $42 \pm 0.11$ years and $56 \%$ of our respondents are between 31 and 50 years old; $20 \%$ are under 30 and $24 \%$ over 50 . The majority are active teachers.

\subsection{Measuring Tool}

The measure of our study was the questionnaire. To obtain a sufficient quantity of responses, we distributed this questionnaire by various means. First, by hierarchical way, we contacted the school heads by email and sent them the questionnaire, which allowed us to collect a hundred responses. Then we disseminated it directly, during educational visits. Finally, we contacted the Pedagogical Physical Education Inspectors in order to distribute our questionnaire on their school site, but the number of respondents was very low because of the weak connection of the internet due to the optical fiber being installation in Congo. However, the completion of a questionnaire completed on condition of anonymity enabled us to collect ultimately 179 usable responses. The objective of this study was presented as exploratory research relating to the evaluative activity of physical education teachers in high schools.

\subsection{Data Collection}

Data collection was done using a questionnaire. To design the questionnaire, we first conducted three interviews with physical education teachers, lasting 30 to 45 minutes, to orient the themes and questions addressed. From there, we defined the field of questioning divided into several items: a Likert scale of attitude at 4 levels and a questionnaire made up of closed questions, open questions, or even mixed questions concerning work of conceptions of the three forms of evaluation: diagnostic, formative and summative [8].

The test lasted 15 to 20 minutes, the questionnaire was tested twice before its final form, the first time in an educational seminar, and the second with ten physical education teachers, different from those then questioned.

\subsubsection{Likert Scale Adapted to Physical Education Teachers}

The Likert scale is a psychometric tool for measuring an attitude in individuals. It is a measurement scale which generally includes 3 to 7 degrees. It is widely used in surveys 
and questionnaires. It allows individuals to be asked about their level of agreement or disagreement with a statement. It is one of the most used scales in satisfaction surveys and questionnaires. As an illustration, the table below represents the filling model of the scale: "the teacher ticks one choice per line, reflecting his opinion on the statement given on the assessment".

Table 1. Model for filling in the Likert scale by teachers.

\begin{tabular}{llll}
\hline & Not at al Okay & Little Okay & Enough Okay \\
\hline Conceptions of physical education teachers & & \\
\hline
\end{tabular}

\subsubsection{Questionnaire for Teachers of Physical Education}

Question 1. Did you use the student co-assessment this year?

Yes $\square$ no $\square$

If yes, when do you use co-assessment the most?

During the diagnostic evaluation: $\square$

During the formative evaluation: $\square$

During the summative evaluation: $\square$

Question 2. Have you really implemented diagnostic assessments this year?

At each cycle $\square$

Sometimes $\square$

Never $\square$

Question 3. Have you implemented formative evaluations this year?

Yes, every cycle $\square$

Yes, sometimes $\square$

No never $\square$

Question 4. Do you ever use a formative assessment to grade your students?

Never: $\square$

Yes sometimes: $\square$

Yes often: $\square$

Yes, systematically $\square$
If yes, can you explain why in a few words?

Question 5. Do you think that the pupils can adopt different motor behaviors (in action, that is to say, apart from social behaviors) between, on the one hand, learning lessons without evaluation, and d 'somewhere else:

Formative evaluation situations: Yes $\square$ no $\square$

Summative evaluation situations: Yes $\square$ no $\square$

\subsubsection{Data Analysis}

The data analysis was carried out using the question data 6 software allowing to cross the collected data to statistically test the existence of relationships between different variables. The open questions were dealt with manually by a content analysis which consists in locating the frequencies of appearance of words, and which creates categories according to the answers provided [9].

\section{Results}

The results obtained are represented in the form of tables interpreting the level of practice of physical sports and artistic activities, the views of teachers of physical education, the frequency of marking, as well as the open and closed questions relating to the functions of the assessment.

Table 2. Assessment of skills according to physical education teachers.

\begin{tabular}{|c|c|c|c|}
\hline Skills & Effective $(\mathrm{N}=179)$ & Percentage (\%) & Significance \\
\hline Physical, social and methodological skills & 91 & 50,83 & $\mathrm{~S}^{*}$ \\
\hline Learning Acquisitions & 34 & 18,99 & NS \\
\hline Level of sports practice & 23 & 12,84 & NS \\
\hline Progress in the execution of the motor image & 11 & 6,14 & NS \\
\hline Personal knowledge, expertise & 7 & 3,91 & NS \\
\hline Performance & 5 & 2,79 & NS \\
\hline Driving lines & 3 & 1,67 & NS \\
\hline Movement success & 4 & 2,23 & NS \\
\hline Ability to complete the task & 1 & 0,55 & NS \\
\hline
\end{tabular}

*(significant); NS (non significant).

Table 3. Measuring the attitude of teachers relative to the different choices of propositions according to the Likert scale.

\begin{tabular}{|c|c|c|c|c|}
\hline & Not at all Okay & Little Okay & Enough Okay & Absolutely Okay \\
\hline I rate to rate. & 9 & 22 & 43 & 26 \\
\hline Formative assessment is useful in helping my students progress & 2 & 1 & 27 & $70 * *$ \\
\hline I evaluate to optimize learning & 5 & 19 & $51 *$ & 25 \\
\hline Summative evaluation motivates my students & 4 & 21 & $53 *$ & 22 \\
\hline The lack of grading leads to a disengagement of my students & 11 & 34 & 43 & 12 \\
\hline Evaluating my students allows me to classify them. & 31 & 33 & 28 & 8 \\
\hline
\end{tabular}

*(significant); ** (very significant) 
Table 4. Frequency of scoring according to the perception of the stress generated in the students.

\begin{tabular}{lllll}
\hline & Not at all Okay & Little Okay & Enough Okay & Absolutely Okay \\
\hline Number of notes on average & 2,79 & 4,46 & 54,18 & 38,54 \\
Significance & NS & NS & S* & NS \\
\hline
\end{tabular}

*(significant); NS (non significant)

Table 5. Teaching staff by age and frequency of grading (question data software 6).

\begin{tabular}{|c|c|c|c|c|c|c|}
\hline & & 20 at 30 & 31 at 50 & More than 50 & Total & $\%$ \\
\hline \multirow{9}{*}{ Number of notes put per cycle } & 1 & 8 & 16 & 16 & 34 & 18,99 \\
\hline & 2 & 13 & 16 & 45 & 94 & $52,51 *$ \\
\hline & 3 & 7 & 7 & 25 & 25 & 13,96 \\
\hline & 4 & 2 & 4 & 3 & 9 & 5,02 \\
\hline & 5 & 0 & 0 & 7 & 7 & 3,91 \\
\hline & 6 & 0 & 0 & 0 & 0 & 0 \\
\hline & 7 & 3 & 0 & 1 & 4 & 2,23 \\
\hline & Total & 36 & 43 & 100 & 179 & \\
\hline & $\%$ & 20,11 & 24,02 & 55,86 & 100 & \\
\hline
\end{tabular}

*(significant)

Table 6. The implementation of formative evaluations according to the question "have you implemented formative evaluations"?

\begin{tabular}{llll}
\hline & Effective (N=179) & Percentage (\%) & Significance \\
\hline At each cycle & 46 & 25,69 & NS \\
Sometimes & 126 & 70,39 & S** \\
Never & 5 & 2,79 & NS \\
Non-respondents & 2 & 1,11 & NS \\
\hline
\end{tabular}

**(very significant); NS (non significant)

Table 7. Scoring formative assessments based on the question "Do you ever use a formative assessment to grade your students?"

\begin{tabular}{llll}
\hline & Effective (N=179) & Percentage (\%) & Significance \\
\hline Never & 37 & 20,67 & NS \\
Sometimes & 120 & 67,03 & S* \\
Often & 12 & 6,70 & NS \\
Systematically & 9 & 5,02 & NS \\
Non - respondents & 1 & 0,55 & NS \\
\hline
\end{tabular}

*(significant); NS (non significant)

\section{Discussion}

Evaluation questions in school education are a major concern of physical education teachers in view of the results obtained in our study. We can distinguish through the answers given by the teachers that formative and summative evaluations shed light on sometimes contradictory implementations, in particular with the expected effects of formative evaluation. For this reason, the differences in responses observed in Table 2 reflect the variety of concepts used in the speeches of physical education teachers. For example, "physical, social and methodological skills" are the most represented $(50.83 \%, \mathrm{n}=91, \mathrm{~S} *)$, referring to the predominance of these notions in school programs. The reference to "learning acquisitions" $(18.99 \%, \mathrm{n}=34, \mathrm{NS})$ is a more general fact that testifies to changes in student behavior due to new skills. "Levels of sporting activity" $(12.84 \%, \mathrm{n}=$ 23 , NS) are widely used in physical education to distinguish themselves from taking only motor performance into account, just like the other skills that have long figured in physical education assessments. In this regard, the function of diagnostic evaluation is becoming a widespread practice among the teachers interviewed, as shown by Braxmeyer et al.,: $41 \%$ of teachers use it systematically and $57 \%$ sometimes [7]. This prognostic function is of direct utility to the specification of work objectives and notional content.

This observation leads us to deepen the conceptions of teachers of PE by proposing to them the scale of Likert in table 3 relating to the measurement of the attitude to the functions of evaluation and its effects on pupils [8]. These results show that in the context of teaching professionalism, the assessment is multifaceted and variegated, as proof, the majority "somewhat - agree" (27\%), "completely agree" $(70 \%)$ suggests that "formative assessment is helpful in helping my students progress." This intention is reinforced in Table 3, which is designated as "somewhat - agree" (43\%) and "completely agree" (26\%) with "I assess to optimize learning". These data show a desire to detach from the traditional function of evaluation perceived as a control step. For Perrenoud, "there are few teachers who resolutely and openly oppose differentiated teaching and formative evaluation [10]. However, they only adhere to it on condition that it is given over the market without compromising any of 
the traditional functions of evaluation." Because formative assessment is intended for learning but, despite its beneficial effects, it would only be optional. In the same vein, Altet reveals that "teachers concerned with modifying their assessment practices and implementing a formative assessment process, also called assessment- regulation, encounter difficulties in the application of this formative evaluation" [11]. Teachers fail to integrate the necessary elements into their usual educational organization and management.

Our results also corroborate the work carried out by Morissette who put forward the idea according to which formative evaluation practices take the form of processes of co-construction of meaning in interaction with students, they belong to a broad system involving the professional culture of teachers as well as their surrounding social environment [12]. The apparent disregard of practices deemed effective and scientifically validated must be understood in their complexity to allow a comprehensive approach, rather than a purely top-down approach aimed at criticizing and prescribing.

However, the findings of our study indicate that scoring is often associated with assessment. Already, with the affirmation in table 3 "I evaluate to rate" $26 \%$ of the teachers are "completely agree", against $9 \%$ "totally disagree", we can safely say that the note helps maintain student engagement, helps students to progress, it is also a source of stress for learners, as proof of the number of notes awarded to students per learning cycle averages 54.18\% (Table 4). For BrauAntony et al., the validity of the proposed grade is not guaranteed because it does not reflect the level of the student but rather the grading methods defined by the teacher [13]. The grade centers the student's attention to the detriment of qualitative assessments intended to help and accompany him in his learning journey. This frequent practice of scoring raises two main problems [14]: the first is that the score measures performance and not learning; the second relates to the biases which largely call into question its reliability and which arouse harmful feelings in pupils [15, 17]. Obviously, our results show that the grade is widely perceived as a source of motivation and commitment for the students, they join the conclusions of Butera et al., which showed that, if the students are can -be motivated by the note, it does not arouse a desire to succeed better than the others [14]. On the contrary, it would rather induce known goals to limit investment and academic performance. The use of the note as a source of motivation would therefore be paradoxical. It should be emphasized that the theories of motivation go in this direction [18] by showing that the external sources of motivation act as constraints placed on the subject and quickly find their limits.

Similarly, the results in Table 5 show that $55.86 \%$ of teachers over the age of $50(n=100)$ rate once or twice per cycle, they are overrepresented among those who rate the least. It should be emphasized that the specificity of the practices of teachers under the age of 50 has already been the subject of research, by Rayou and Van Zanten who raised their difficulty in managing complexity due to lack of professionalization [1]. On the subject, Boraita and Issaieva have shown that the conceptions of evaluation of young teachers in training are different from those of active teachers [19]. Indeed, depending on professional experience or even the level of expertise, the priorities of teachers are not the same and involve different pedagogical choices. The usefulness of evaluations is thus translated in different ways, even if at the outset the intentions seem similar. To this, it must be added that the experience and age of the teachers interviewed plays in favor of taking into account the harmful effects of evaluation and the value of formative evaluations, for example $52,51 \%$ of teachers offer them in cycle 2 (Table 5 ) and among them, those over 50 are overrepresented ( $\mathrm{n}=$ 45). This can no doubt be justified by the fact that the effects of scoring show an attachment to formative assessment, but the strong presence of scoring taints this desire to use assessment in the service of learning. Here we observe a representation of the notes which does not take into account the harmful effects which may result therefrom.

In addition, formative evaluation is thus considered as a stage in the acquisition of learning in physical education. It informs students about their level of sports practice at school, but quantitatively with a note. It is true similar that the crossover of our results obtained in table 6 , relating to the implementation of formative evaluations show only $(25.69 \%$, $\mathrm{n}=46, \mathrm{NS})$ of the teachers propose a formative evaluation "at each cycle", $(70.39 \%, \mathrm{n}=126, \mathrm{~S} * *)$ of teachers "sometimes" and $(2.79 \%, \mathrm{n}=5, \mathrm{NS})$ of teachers "never" rate it. Despite the desire of physical education teachers to help students progress, our results show a low level of practice that does not always go in the direction of learning aid, because the assessment changes its purpose. Also, almost all teachers set up formative evaluations, more or less regularly, but divergences appear with regard to the implementation.

As for the results obtained in Table 7, the responses recorded show that $(20.67 \%, \mathrm{n}=37$, NS) of teachers say they "never" rate the formative evaluation, $(67.03 \%, \mathrm{n}=120, \mathrm{~S} *)$ teachers rate "sometimes", $(6.70 \%, \mathrm{n}=12, \mathrm{NS})$ teachers rate "often" and $(5.02 \%, \mathrm{n}=9, \mathrm{NS})$ teachers rate "systematically". In view of these results, we can say that teachers put on average more than four marks per cycle of eight lessons.

In view of the above, we can say that this study made it possible to wonder about the multiple effects of evaluation with students (commitment, stress, etc.), because these effects are not perceived in the same way by all. The variety of practices appealed to different conceptions of the definition, functions and effects of evaluation. The representations functioned as an interpretive filter where the object and the subject were interdependent. [20] They thus allow the subject to give meaning to his behavior. In fact, the differences noted have witnessed the subject's freedom to interpret the knowledge he has acquired, to construct his representations over the course of his experience and according to the environment in which he acts. Indeed, Rayou and Zanten have shown that, for young teachers, teaching is a work of complex adaptation to the context of 
which the public has been a central element [1]. The lack of professionalization of their training, raised by these young teachers, was a real problem in learning to manage diversity.

\section{Conclusion}

The purpose of the study was to analyze the views of teachers in Brazzaville on assessment in physical education at school. The results obtained demonstrate the interpretation of the different forms of assessment offered to high school students, as well as their adaptation to teaching contexts. They also take into account the gap that exists between the discourse and the teachers' conceptions specific to the evaluation of students, while specifying that these results remain specific in physical education, which prevents any generalization. Also, there is a misinterpretation of the formative function of the assessment by some of the teachers interviewed. For motor learning, its interest has been recognized but the concern to optimize the students' investment has regularly resulted in a rating of the formative evaluation, thus changing its purpose. Through its definition, the teachers interviewed gave meaning to the learning, the evaluation and the utility attributed to formative evaluation and above all to the real expertise of each physical education teacher. Thus, the reflexive analysis of this practical conception should benefit from a special place in the training of pupils in high school in order to favor the didactic adaptation in the management of the physical life of the learners and who serve us as reference social practices. In the society. In any case, professional activity is never a reflection of prescription.

\section{References}

[1] Rayou, P., et Van Zanten, A. (2004). Enquête sur les nouveaux enseignants. Changeront-ils l'école ? Paris: Bayard.

[2] Bressoux, P., Bru, M., Altet, M., et Lambert, C. (1999). Diversité des pratiques d'enseignement à l'école élémentaire, Revue Française de Pédagogie, 97-110 (126).

[3] Becker, H,. S. (1963). Outsiders. Études de sociologie de la déviance (trd. J.-P. Briand et J.-M. Chapoulie 1985). Paris: Éditions A.-M. Métailié.

[4] Marcel, J.-F., Dupriez, V., Perisset, D. et Tardif, M. (2007). Coordonner, collaborer, coopérer: de nouvelles pratiques enseignantes. Bruxelles: De Boeck.
[5] Leplat, J. (1986). L'analyse psychologique du travail. Revue de Psychologie Appliquée, 9-27 (31).

[6] Figari, G. (1994). Évaluer: quel référentiel ? Bruxelles: De Boeck-Wesmael.

[7] Braxmeyer, N., Guillaume, J.-C., et Levy, J.-F. (2004). Les pratiques d'évaluation des enseignants en collège. Note de la DEP 04.13.

[8] Likert, R. (1932). A Technique for the Measurement of Attitudes, Archives of Psychology, 1-55 (140).

[9] Bardin, L. (1977). L'analyse de contenu. Paris: PUF.

[10] Perrenoud, P. (1998). L'évaluation des élèves. De la fabrication de l'excellence à la régulation des apprentissages. Bruxelles: De Boeck.

[11] Altet, M. (2001). Pratiques d'évaluation et communication en classe. In G. Figari and M. Achouche. L'activité évaluative réinterrogée, 78-83. Bruxelles: De Boeck.

[12] Morissette, J. (2010). Une perspective interactionniste. Un autre point de vue sur l'évaluation des apprentissages. Revue de l'Association Internationale des Sociologues de Langue Française. Disponible sur internet: http:// sociologies. Revues. org/ 3028 .

[13] Brau-Antony, S., et Cleziou, J.-P. (2005). L'évaluation en EPS: Concepts et contributions actuelles. Paris: Actio.

[14] Butera, F., Buchs C., et Darnon, C. (2011). L'évaluation, une menace? Paris: PUF.

[15] Merle, P. (2007). Les notes: secrets de fabrication. Paris: PUF.

[16] Vantourout, M., et Goasdoue, R. (2010). Correction de dissertations: analyse de l'activité de professeurs engagés dans une approche par compétences. Actes du congrès de l'Actualité de la Recherche en Éducation et Formation, Université de Genève.

[17] Monteil, J.-M. \& Huguet P. (1999). Social context and cognitive performance: Towards a social psychology of cognition. Hove: Psychology Press.

[18] Deci, E.-L., \& Ryan, R.-M. (1985). Intrinsic motivation and self-determination in human behavior. New York: Plenum Press.

[19] Boraita, F., et Issaieva, E. (2013). Les conceptions de l'évaluation chez les futurs enseignants et enseignants en exercice: une étude dans le canton de Genève. Actes du colloque Admee 2013. Disponible sur internet: http:// www.admee2013.ch/ADMEE2013/7 files/Boraita-Issaieva-ADMEE-2013.Pdf.

[20] Abric, J.-C. (1987). Coopération, compétition et représentations sociales. Cousset: Delval. 